\title{
Interactive effects of excess boron and salinity on response curves of gas exchange to increase in the intensity of light of Zea mays amylacea from the Lluta Valley (Arica-Chile)
}

\author{
Efectos interactivos del exceso de boro y salinidad en las curvas de respuestas \\ del intercambio gaseoso con el aumento de la intensidad de la luz en Zea mays \\ amylacea del Valle de Lluta (Arica-Chile) \\ Elizabeth Bastías ${ }^{1}$, María B. González-Moro², Carmen González-Murua ${ }^{2}$
}

\begin{abstract}
High levels of B (boron) are accompanied by conditions of excessive salinity, as occurs in the Lluta Valley in northern Chile; the consequences can be drastic for crops. In the present study, seeds of Zea mays L. amylacea were grown in order to study the response curves of gas exchange to increase in the intensity of light at high levels of $\mathrm{NaCl}$ and $\mathrm{B}$. Concentrations of $100 \mathrm{mM} \mathrm{NaCl}$ (low salinity) or $430 \mathrm{mM} \mathrm{NaCl}$ (high salinity), or an excess of B supplied as boric acid to obtain 20 and $40 \mathrm{mg} \mathrm{kg}^{-1} \mathrm{~B}$ were applied in the nutrient solution for 20 days. Our results complement other studies with the amylacea ecotype and confirm the high degree of tolerance to salinity and excess boron. Higher light intensified the gas exchange parameters photosynthetic rate, transpiration rate and $\mathrm{CO}_{2}$ stomatal conductance, which gradually increased. Intercellular $\mathrm{CO}_{2}$ concentration and water-use efficiency (WUE) showed no differences between treatments, except for high leaf $\mathrm{CO}_{2}$ at high salinity. The plants grown under high salt, independent of the presence of $\mathrm{B}$, showed a high quantum requirement at higher light intensities.
\end{abstract}

Key words: Amylacea, boron, salinity, intensity of light.

\section{RESUMEN}

Los altos niveles de B (boro) acompañados por condiciones de excesiva salinidad, como ocurre en el valle de Lluta en el norte de Chile; cuyas consecuencias pueden ser drásticas para los cultivos. En el presente estudio, semillas de Zea mays L. amylacea fueron sembradas con el fin de estudiar las curvas de respuesta de intercambio gaseoso con el aumento la intensidad de la luz. en condiciones de altos niveles de $\mathrm{NaCl}$ y B. Las concentraciones fueron de $100 \mathrm{mM} \mathrm{NaCl}$ (baja salinidad) o $430 \mathrm{mM} \mathrm{NaCl}$ (alta salinidad), o un exceso de B suministrado como ácido bórico para obtener concentraciones 20 y $40 \mathrm{mg} \mathrm{kg}^{-1}$ B que se aplicó en la solución nutritiva durante 20 días. Nuestros resultados complementan los estudios anteriores del ecotipo amylacea y confirman el alto grado de tolerancia a la salinidad y al exceso de B. Una alta intensidad lumínica intensifica los parámetros de intercambio gaseoso como tasa fotosintética, tasa de transpiración y la conductancia estomática que aumenta en forma gradual. La concentración de $\mathrm{CO}_{2}$ intercelular y la eficiencia del uso del agua (EUA) no mostraron diferencias entre los tratamientos, excepto a alta salinidad. Las plantas que crecen en condiciones de alta salinidad, independiente de la presencia de B, mostraron un alto requerimiento cuántico a altas intensidad de luz.

Palabras clave: amylacea, boro, salinidad, intensidad de luz.

\section{Introduction}

By 2050, a $30 \%$ increase in grain yield is a prerequisite to fulfill the food requirement of the growing population (Borlaug, 2000; Edgerton, 2009). Thus further improvement in photosynthesis is necessary for increased production of food and fuel. With the Green Revolution beginning in the sixties, grain yields have doubled worldwide (Tilman et al., 2001; Araus et al., 2008). This has been achieved not only by releasing genotypes with higher biomass partitioning to grains, i.e. higher harvest

1 Departamento de Producción Agrícola, Centro de Agricultura y Biodiversidad del Desierto (CAyBIDE), Facultad de Ciencias Agronómicas, Universidad de Tarapacá. Casilla 6-D, Arica, Chile.

2 Departamento de Biología Vegetal y Ecología, Facultad de Ciencia y Tecnología, Universidad del País Vasco/Euskal Herriko Unibertsitatea. Apdo. 644, E-48080 Bilbao, Vizcaya, Spain.

* Corresponding Author: ebastias@uta.cl

Fecha de Recepción: 21 Agosto, 2014.

Fecha de Aceptación: 19 Noviembre, 2014. 
index (Araus et al., 2008), but also by increasing the use of pesticides, fertilizers and notably, water for irrigation (Tilman et al., 2002). According to FAO (2008), over $6 \%$ of world land is affected by salinity, covering about 4 Mha. Salinity is rapidly increasing on a global scale and currently affects more than $10 \%$ of arable land, which results in a decline of the average yield of major crops greater than 50\% (Wang et al., 2003). Up to 50-70\% decline in major crop productivities have been attributed to abiotic stresses on several occasions (Mittler, 2006). Water shortage, extreme temperatures and high salinity are some of the most devastating environmental stresses for crops, leading to depletion in cell water content and osmotic potential, thereby causing osmotic stress and yield losses (Ahuja, 2010; Zhang et al., 2011).

Boron as an essential element for higher plants, $B$ deficiency and B toxicity are a worldwide problem in food production because they reduce crop quality and yields in soils, especially in arid areas (Nable et al., 1997). Salinity conditions are aggravated by the presence of boron (B) in soils and water in arid and semiarid environments. This the case in the Lluta valley of northern Chile, where elevated levels of B in soils and irrigation water limit local agricultural production to a few landrace crops of this region, which has less than $1 \mathrm{~mm}$ annual precipitation (Bastías et al., 2004b). Zea mays L. amylacea is a sweet maize variety well adapted to the agro-ecological characteristics of the Lluta Valley; the physiological mechanisms of tolerance to high levels of $\mathrm{NaCl}$ and $\mathrm{B}$ in amylacea maize have been studied previously with respect to the salt accumulation capacity of tissues, photosynthetic assimilation and water relations (Bastías et al., 2004b), as well as root hydraulic conductance (Lo), abundance of aquaporins and ATPase activity (Bastías et al. 2004a, Martínez-Ballesta et al., 2008). Additionally, other studies at the leaf and root levels have been published (Bastias et al., 2013a, Bastias et al., 2013b) showing the degree of tolerance to salinity and excess B.

Salinity and shade were chosen because they impact on photosynthesis through contrasting effects on leaf $\mathrm{CO}_{2}$ diffusion and fixation. Mild to moderate salinity inhibits root water uptake, thus indirectly reducing the plant water status, as detected by increased leaf water potential and reduced stomatal conductance, both of which reduce photosynthesis (Omoto et al., 2012). Low light reduces photosynthesis mainly by reducing activity and activation of photosynthetic enzymes (Edwards et al., 1985).

The objective of this study was to determine the extent to which physiological parameters related to photosynthetic function may limit growth of the amylacea cultivar under stress by excess $B$ and salinity at different light intensities.

\section{Materials and Methods}

\section{Growth conditions and experimental design}

Seeds of the maize germplasm native to Northern Chile, Zea mays amylacea ("lluteño" local variety), were germinated in a mixture of perlite and vermiculite $(1: 1 ; \mathrm{v} / \mathrm{v})$. Seedlings were grown in $2 \mathrm{~L}$ plastic pots with four plants per pot, and irrigated every two or three days to maintain soil water at field capacity with Hoagland solution containing $20 \mathrm{mM} \mathrm{NO}_{3}-\mathrm{N} / \mathrm{L}$ (González-Moro et al., 1997) adjusted to $\mathrm{pH} 5$ 5.5. Placement of maize pots was completely randomized. Plants were grown in a greenhouse with an average day/night temperature of $25 / 18^{\circ} \mathrm{C}$, and relative humidity of $60 / 70 \%$, respectively. Light intensity was set at $350 \mu \mathrm{mol}$ $\mathrm{m}^{-2} \mathrm{~s}^{-1}$ and supplemented with warm-white lamps (Philips SON-T AGRO 400, Belgium), providing a $14 \mathrm{~h}$-photoperiod. Nutrient solutions were prepared using deionized water, and $\mathrm{pH}$, osmotic potential and conductivity were monitored weekly. During the first ten days after germination plants were irrigated with the basic nutrient solution to maintain non-saline growing conditions. Subsequently, when plants showed the third leaf fully expanded, they were exposed to an excess of boron and salt for 20 days. The basic nutrient solution without addition of salt ( $\mathrm{NaCl}-0)$ or boron (B-0) was used as the control solution. This basic nutrient solution was supplemented in a factorial design with $100 \mathrm{mM}$ $\mathrm{NaCl}$ (Low salinity, L) or $430 \mathrm{mM} \mathrm{NaCl}$ (High salinity, $\mathrm{H})$, and with an excess of B supplied as boric acid to obtain $20(334 \mu \mathrm{M})$ or $40(668 \mu \mathrm{M})$ $\mathrm{mg} \mathrm{B} \mathrm{kg}{ }^{-1}$ in the nutrient solution.

\section{Gas exchange measurements}

Net photosynthetic $(A)$ and transpiration rates $(E)$, stomatal conductance, the internal concentration of $\mathrm{CO}_{2}$ in the mesophyll $(\mathrm{Ci})$, efficiency in the instantaneous use of water (WUE $=\mathrm{A} / \mathrm{E})$ and quantum 
requirement $(\mathrm{QR})$ was measured on the third fully expanded young leaves between 11:00 and 12:00 using a LI-6400 portable photosynthesis system (Li-Cor, Lincoln, NE, USA) with an infra-red gas analyzer (IRGA), to measure the radiant flux density incident on the leaves and make assessments of the response curves of photosynthesis to variations in light intensity. These measurements were performed using the Autoprogram Li-6400. The response curves were measured in the light at constant external concentration of $\mathrm{CO}_{2}$, the temperature of the air surrounding the leaves and subjecting the leaves to increasing intensities of radiation $(400,700$ and $1200 \mathrm{mmol}$ photon $\mathrm{m}^{-2} \mathrm{~s}^{-1)}$. The acclimation time between consecutive light intensities was established between 10-15 min.

\section{Statistical analysis}

The experimental data were analyzed by ANOVA and the differences were compared by employing the Duncan test with a significance of $\mathrm{P} \leq 0.05$ using the SPSS software, version 11/ PC (SPSS 11.0, 2001). All experiments described were repeated three times independently with six replications each time.

\section{Results}

In plants of Zea mays L. amylacea the $\mathrm{CO}_{2}$ assimilation rate increased, as expected, with increasing light intensity (Figure 1a) in plants grown under non-saline and low salinity (100 mM). Thus, the response of photosynthetic rate with increasing photosynthetic photon flux density (DFFF) was similar in these treatments and assimilation reached values above $18 \mathrm{mmol} \mathrm{CO} \mathrm{Cm}^{-2} \mathrm{~s}^{-1}$ at high light intensity $\left(1200 \mu \mathrm{mol}\right.$ photon $\left.\mathrm{m}^{-2} \mathrm{~s}^{-1}\right)$. Applying B levels considered toxic to many crops did not affect the rate of assimilation in non-saline conditions and low salinity. The opposite was true in non-saline conditions; maximum net photosynthetic rates of 25.15 and $20.89 \mu \mathrm{mol} \mathrm{CO}_{2} \mathrm{~m}^{-2} \mathrm{~s}^{-1}$ were observed in plants grown with 20 and $40 \mathrm{mg} \mathrm{B} \mathrm{kg}^{-1}$, respectively.

Conversely, under high salt conditions (430 $\mathrm{mM} \mathrm{NaCl}$ ) the increased light intensity did not increase $\mathrm{CO}_{2}$ assimilation, showing a luminous point near saturation $450 \mu$ mol photon $\mathrm{m}^{-2} \mathrm{~s}^{-1}$ and maximum values of $\mathrm{CO}_{2}$ assimilation of about 5-6 $\mu \mathrm{mol} \mathrm{CO} \mathrm{Cm}^{-2} \mathrm{~s}^{-1}$. That is, at $430 \mathrm{mM} \mathrm{NaCl}$ this reduction corresponds to a decrease of more than
$60 \%$ of $\mathrm{CO}_{2}$ assimilation at high light intensity $\left(1200 \mu \mathrm{mol}\right.$ photon $\left.\mathrm{m}^{-2} \mathrm{~s}^{-1}\right)$ relative to control plants. However, it was observed that inhibition of the uptake of $\mathrm{CO}_{2}$ was mitigated in part when $\mathrm{B}$ was applied. Values of 8.72 and $5.32 \mu \mathrm{mol} \mathrm{CO}_{2} \mathrm{~m}^{-2} \mathrm{~s}^{-1}$ were reached when $B$ was present at 20 and $40 \mathrm{mg}$ $\mathrm{B} \mathrm{kg}^{-1}$, respectively. The behavior of the response of transpiration rate versus DFFF increase (Figure 1b) was similar to that observed for $\mathrm{CO}_{2}$ assimilation. Plants grown in non-saline conditions and low salt $(100 \mathrm{mM} \mathrm{NaCl})$ had significantly higher rates of transpiration, with values between $1.53 \mathrm{mmol} \mathrm{H}_{2} \mathrm{O}$ $\mathrm{m}^{-2} \mathrm{~s}^{-1}$ at a light intensity of $700 \mu \mathrm{mol}$ photon $\mathrm{m}^{-2} \mathrm{~s}^{-1}$ and $2.05 \mathrm{mmol} \mathrm{H}_{2} \mathrm{O} \mathrm{m}^{-2} \mathrm{~s}^{-1}$ at $1200 \mu \mathrm{mol}$ photon $\mathrm{m}^{-2} \mathrm{~s}^{-1}$. The transpiration rate under high salinity and the presence of $\mathrm{B}$ remained at values around 0.83 $\mathrm{mmol} \mathrm{H} \mathrm{O} \mathrm{m}^{-2} \mathrm{~s}^{-1}$ for the light intensities tested.

The values of stomatal conductance $\left(\mathrm{g}_{\mathrm{s}}\right)$, given in Figure 1c, showed that stomatal opening responded to increased DFFF, presenting a similar behavior to that observed for $\mathrm{CO}_{2}$ assimilation rate and transpiration rate. Gs values under non-saline and low salinity were always greater than 0.11 mol air $\mathrm{m}^{-2} \mathrm{~s}^{-1}$ and increased at high light intensity $\left(1200 \mu \mathrm{mol} \mathrm{m}^{-2} \mathrm{~s}^{-1}\right)$ to values between 0.13-0.16 mol air $\mathrm{m}^{-2} \mathrm{~s}^{-1}$. Under high salinity $(430 \mathrm{mM} \mathrm{NaCl})$ $\mathrm{g}_{\mathrm{s}}$ was significantly lower compared to non-saline conditions and low salinity, with values around $0.04 \mathrm{~mol}$ air $\mathrm{m}^{-2} \mathrm{~s}^{-1}$.

As described in previous studies (Bastias et al., 2004b) stomatal conductance decreased $40 \%$ under high salinity with $350-400 \mu \mathrm{mol}$ photon $\mathrm{m}^{-2} \mathrm{~s}^{-1}$. Unlike what was observed for $\mathrm{CO}_{2}$ assimilation, the presence of B did not mitigate the effect of salinity on stomatal conductance at high salinity. Thus equal values of stomatal opening were observed in a range of light intensity between $400-1200 \mu \mathrm{mol}$ photon $\mathrm{m}^{-2} \mathrm{~s}^{-1}$.

Plants grown under non-saline and low salinity $(100 \mathrm{mM} \mathrm{NaCl})$ conditions showed no significant differences between the values of the intercellular $\mathrm{CO}_{2}$ concentration $(\mathrm{Ci})$; the lowest concentration occurred in plants under saline conditions, with values between 60 and $75 \mathrm{ppm} \mathrm{CO}_{2}$. Increasing light intensity showed no significant effect on intercellular $\mathrm{CO}_{2}$ concentration. The plants grown in high salt in the absence $\mathrm{B}$ had a higher internal concentration of $\mathrm{CO}_{2}$, about $120 \mathrm{ppm} \mathrm{CO}_{2}$, possibly as a consequence of the inhibition of uptake. However, with the application of $\mathrm{B}$ at high salinity $C \mathrm{i}$ values were similar to those of the plants not salt-treated 

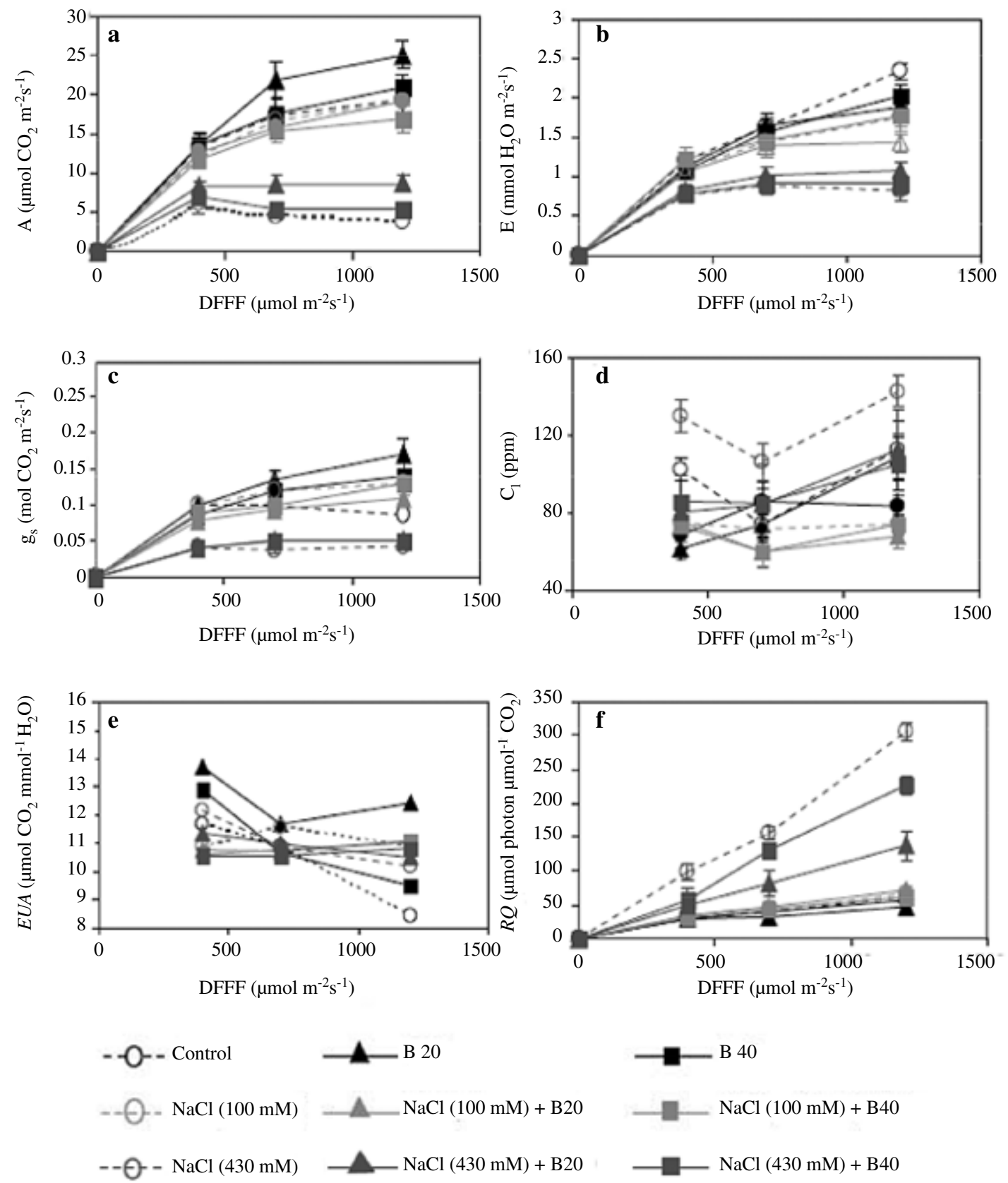

Figure 1: Net assimilation rate $(A)$, transpiration rate $(E)$, stomatal conductance $(g \mathrm{~s})$, intercellular $\mathrm{CO}_{2}$ concentration $(C \mathrm{i})$, water use efficiency (WUE) and quantum requirement (QR) at various DFFF: 400, 700 and $1200 \mu \mathrm{mol} \mathrm{photon} \mathrm{m-}{ }^{2} \mathrm{~s}^{1}{ }^{1}$ in Zea mays L. amylacea leaves after 20 days of treatment with $\mathrm{B}$ and $\mathrm{NaCl}$.

and with low salinity, reflecting a slight recovery of the uptake (Figure 1d).

The graphical representation of the values obtained for water use efficiency (WUE) under different light intensities is shown in Figure 1e. The trend of the instantaneous WUE showed no significant differences between the treatments or with increasing light intensity. Thus this cultivar maintains values between $12.7 \mu \mathrm{mol} \mathrm{CO} \mathrm{mmol}^{-1}$ $\mathrm{H}_{2} \mathrm{O}$ for non-saline conditions and $10.5 \mu \mathrm{mol} \mathrm{CO}_{2}$ $\mathrm{mmol}^{-1} \mathrm{H}_{2} \mathrm{O}$ for high salt conditions at high light intensity $\left(1200 \mu \mathrm{mol} \mathrm{m} \mathrm{m}^{-2} \mathrm{~s}^{-1}\right)$. This highlights an 
important feature, since the ecotype can maintain similar values of WUE at a salt concentration of $430 \mathrm{mM} \mathrm{NaCl}$ and high light intensity, suggesting a good stomatal control that minimizes water loss.

The quantum requirement (QR; Figure 1f) in plants grown under non-saline and low salinity was similar, with values between 29.52 and $33.79 \mathrm{mmol}$ photon $\mu \mathrm{mol}^{-1} \mathrm{CO}_{2}$, but there was a tendency to increase with increasing light intensity. However, in high salt conditions there was a significant increase of about 5 times the number of photons required for assimilation of one mole of $\mathrm{CO}_{2}$. QR increased proportionally to increase of light intensity and reduction of $A$. The addition $\mathrm{B}$ of at medium under conditions of high salinity produced a low QR increase compared to saline treatment only, indicating greater utilization of light energy in the presence of B under saline condition.

\section{Discussion}

Due to the good behavior of gas exchange parameters of the amylacea ecotype under stress conditions and conditions of light intensity of 350-400 $\mu \mathrm{mol}$ photon $\mathrm{m}^{-2} \mathrm{~s}^{-1}$ DFFF (Bastias et al., 2004b), we studied the behavior of the photosynthetic capacity in response to higher light intensities. This assessment considered the place of origin of this ecotype, Lluta Valley. In this region, a coastal desert climate, the intensity of light that reaches throughout the day is very high, especially at noon, close to $1200 \mu \mathrm{mol}$ photon $\mathrm{m}^{-2} \mathrm{~s}^{-1}$. This suggests that this ecotype must have a good system of capturing energy and regulation of photosynthetic and photochemical processes so the physiology of the plant is not altered by agroecological conditions, considering that it is a $\mathrm{C}_{4}$ plant with a high capacity to capture light energy.

In the gas exchange parameters at higher light intensities (Figure 1), the photosynthetic rate gradually increased with increasing light intensity as expected, indicating the potential of this ecotype to use high intensities of light in a saline medium
(100 mM NaCl). Only at high salt concentrations $(430 \mathrm{mM} \mathrm{NaCl})$, the saturation of the photosynthetic rate at low light intensities foretells possible structural damage or limitation of the biochemical machinery involved in the assimilation of $\mathrm{C}$.

The instantaneous WUE showed no significant differences between the treatments or with increasing light intensity. Furthermore, the values WUE obtained for this ecotype were significantly greater than in other maize varieties. This highlights an important feature of this ecotype, as it manages to maintain similar values of WUE at a salt concentration of $430 \mathrm{mM} \mathrm{NaCl}$ and high light intensity, suggesting good stomatal control that minimizes water loss and achieves high efficiency of water use (Hsiao, 1993, Rivelli et al., 1998; Rivelli et al., 2002).

Plants grown under non-salt and low salt conditions, independent of the presence of $\mathrm{B}$ showed a low quantum requirement, which is indicative of good function of photosystem II; the demand for smaller energy amount photosynthetic fixation similar (Lichtenthaler and Babani, 2000). However, at high salinity conditions a considerable increase in quantum request occurred, which was proportional to the increase of the light intensity and decreased photosynthesis. The high input of energy in saline conditions could result in severe and irreversible changes in the photochemical apparatus, a control in photosystem II (Calatayud et al., 1997) or a decrease in the efficiency of the photochemical machinery. This suggests that high light intensity could be producing some degree of photoinhibition in this ecotype, although one cannot rule out an effect of $\mathrm{Na}^{+}$on the photochemical system or joints charge of $\mathrm{CO}_{2}$ assimilation.

\section{Acknowledgements}

This study was funded partly by Project UTA-Mayor 9721-13; UTA-Mayor 9720-13 and Project Innova-Corfo Código 09CN 14-58770 (Arica-Chile).

\section{Literature Cited}

Ahuja, I.

2010. Plant molecular stress responses face climate change. Trends in Plant Science, 15: 64-674.

Araus, J.L.; Slafer, G.A.; Royo, C. Serret, M.D.

2008. Breeding for yield potential and stress adaptation in cereals. Critical Reviews in Plant Science, 27: 377-412.
Bastías, E.; Fernández-García, N.; Carvajal, M. 2004a. Aquaporin functionality in rotos of Zea mays in relation to the interactive effects of boron and salinity. Plant Biology, 6: 415-421.

Bastías, E.; González-Moro, M.B.; González-Murua, C. 2004b. Zea mays L. amylacea from the Lluta Valley (Arica- 
Chile) tolerates salinity stress when high levels of boron are available. Plant and Soil, 267: 73-84.

Bastías, E.; González-Moro, M.B.; González-Murua, C.

2013a. Interactive effects of excess boron and salinity on histological and ultrastructure leaves of Zea mays amylacea from Lluta Valley (Arica-Chile). Ciencia e Investigación Agraria, 40: 589-603.

Bastías, E.; González-Moro, M.B.; González-Murua, C. 2013b. Leaf micromorphology in Zea mays amylacea from Lluta Valley (Arica-Chile) with excess boron and salinity. Idesia, 31: 75-80.

Borlaug, N.E.

2000. The green revolution revisited and the road ahead. Special 30th Anniversary Lecture, Norwegian Nobel Institute, Oslo.

Calatayud, A.; Deltoro, V. I.; Barreno, E.; Valle-Tascon, S.D.

1997. Changes in in vivo chlorophyll fluorescence quenching in lichen thalli as a function of water content and suggestion of zeaxanthin-associated photoprotection. Physiologia Plantarum, 101: 93-102.

Edgerton, M.D.

2009. Increasing crop productivity to meet global needs for feed, food, and fuel. Plant physiology, 149: 7-13.

Edwards, G.E.; Nakamoto, H.; Burnell, J.N.; Hatch, M.D. 1985. Pyruvate, Pi dikinase and NADP-malate dehydrogenase in C4 photosynthesis: properties and mechanism of light/ dark regulation. Annual review of plant physiology, 36: 255-286.

FAO

2008. Land and Plant Nutrition Management Service. http:// www.fao.org/ag/agl/agll/spush

González-Moro, B.; Lacuesta, M.; Becerril, J.M.; González-

Murua, C. ; Muñoz-Rueda, A.

1997. Glycolate accumulation causes a decrease of photosynthesis by inhibiting RUBISCO activity in maize. Journal of Plant Physiology, 150: 388-394.

Hsiao, T. C.

1993. Effects of drought and elevated CO2 on plant water use efficiency and productivity. In Interacting stresses on plants in a changing climate (pp. 435-465). Springer Berlin Heidelberg, Germany.

Lichtenthaler, H. K., Babani, F.

2000. Detection of photosynthetic activity and water stressby imaging the red chlorophyll fluorescence. Plant Physiology and Biochemistry, 38: 889-895.

Martínez-Ballesta, M.C.; Bastías, E.; Zhu, C.; Schäffner, A.R.;

González-Moro, B.; González-Murua, C.; Carvajal, M.

2008. Boric acid and salinity effects on maize roots. Response of aquaporins $Z m P I P 1$ and $Z m P I P 2$, and plasma membrana $\mathrm{H}^{+}$-ATPase, in relation to water and nutrient uptake. Physiology Plantarum, 132: 479-490.

Mittler, R.

2006. Abiotic stress, the field environment and stress combination. Trends in Plant Science, 11: 1-19.

Nable, R.O.; Bañuelos, G.S.; Paull, J.G.

1997. Boron Toxicity. Plant and Soil, 193: 181-198.

Omoto, E.; Taniguchi, M.; Miyake, H.

2012. Adaptation responses in C sub 4/sub photosynthesis of maize under salinity. Journal of plant physiology, 169: 469-477.

Rivelli, A. R.; Lovelli, S.; Perniola, M.

2002. Effects of salinity on gas exchange, water relations and growth of sunflower (Helianthus annuus). Functional Plant Biology, 29: 1405-1415.

Tilman, D., Cassman, K.G.; Matson, P.A.; Naylor, R.; Polasky, S. 2002. Agricultural sustainability and intensive production practices. Nature, 418: 671-677.

Wang, W., Vinocur, B.; Altman, A.

2003. Plant response to drought, salinity and extreme temperature: towards genetic engineering for salt stress tolerance. Planta, 218: 1-140.

Zhang K., Guo, Lian L., N. ; Wang, J. Lv., ; Zhang, . J.

2011. Improved salt tolerance and seed cotton yield in cotton (Gossypium hirsutum L.) by transformation with betA gene for glycinebetaine synthesis. Euphytica, 181: 1-16. 